\title{
Prawne podstawy cenzury prasy w okresie stanu wojennego w Polsce (1981-1983)
}

I. Cenzura w okresie PRL jest przedmiotem zainteresowania i opisu historyków, literaturoznawców, kulturoznawców, prawników, a także cenzorów ${ }^{1}$, ujmujących stan wojenny bądź jako kolejny etap opisu zjawiska cenzury lub prasy; jako element opisu zjawiska propagandy w okresie PRL; jako mechanizm wywierania wpływu, poprzez pryzmat funkcjonowania prasy niezależnej w tym okresie.

Stosunkowo niewiele jest opracowań dotyczących cenzury stricte w okresie stanu wojennego. Wśród nich przeważają pozycje poświęcone cenzurze w odniesieniu do określonych terytorialnie regionów, (miast) Polski w okresie stanu wojennego lub charakteryzujące różne ograniczenia wolnościowe w tym okresie, czy też będące zestawieniem dokumentów archiwalnych z tego okresu, w tym także poświęconych cenzurze ${ }^{2}$.

\footnotetext{
${ }^{1}$ Zob. np. Cenzura w PRL, relacje historyków, oprac. Z. Romek, Warszawa 2000; Cenzura w latach 1946-1949, statystyka działalności, red. A. Paczkowski, „Zeszyty Historyczne”, z. 116, 1996, s. 22-57; L. Hass, Cenzura i inne mechanizmy sterowania historykami w PRL. (Osobiste doświadczenia i przemyślenia), „Mazowieckie Studia Humanistyczne”, 1997 nr 2, s. 85-102; Solidarność podziemna 1981-1989, pod red. A. Friszke, Warszawa 2006; W. Pepliński, Cenzura jako element propagandy PRL, (w:) Propaganda PRL, Wybrane problemy, pod red. P. Semkowa, Gdańsk 2004, s. 14-21; Ł. Kamiński, Struktura propagandy PRL, (w:) Propaganda PRL: wybrane problemy, pod red. P. Semkowa, Gdańsk 2004, s. 10-12; A.M. Dereń, Ważniejsze czasopisma niezależne na Dolnym Ślasku w latach 1980-81, (w:) Polityczno-prawne aspekty walki politycznej i konfliktów społecznych $w$ Polsce $w$ latach 1980-83, pod red. M. Izbickiej, Wrocław, 1994; Wolność słowa epoki Stalina, „Biuletyn IPN”, 2003/2-4, s. 5-8; Polskie radio na Pomorzu i Kujawach 1935-2005, pod red. W. Jastrzębskiego, M. Rzepy, Bydgoszcz 2005; Media w PRL, PRL w mediach, Materiaty z II Ogólnopolskiej Konferencji Propaganda PRL, Gdańsk 19-20 listopada 2003 r., red. M. Malinowski, P. Niwiński, T. Dmochowski, Gdańsk-Warszawa 2004; P. Misiorny, Ja, Tomasz Strzyżewski, Kraków 1997.

${ }^{2}$ Zob. np. E. Kułakowska, Stan wojenny w gorzowskiej prasie, „Nadwarciański Rocznik Historyczno-Archiwistyczny”, nr 14/2007, s. 267-280; Stan wojenny w dokumentach władz PRL 19801983, pod red. B. Kopka i G. Majchrzaka, Warszawa 2001; Stan wojenny w Polsce. Dokumenty i materiaty archiwalne 1981-1983, pod red. T. Walichnowskiego, Warszawa 2001; Z. Radzikowska, Z historii walki o wolność stowa w Polsce cenzura $w$ okresie PRL w latach 1981-1987, Kraków
} 
Nie ulega jednak wątpliwości, że okres stanu wojennego w kontekście cenzury zasługuje na refleksję prawniczą, gdyż już z pobieżnego oglądu wynika, że charakteryzował się wprowadzeniem ustawodawstwa o charakterze opresyjnym, w zakresie wielu swobód obywatelskich, w tym także wolności słowa.

Tematyka artykułu wpisuje się także w szerszą perspektywę poznawczą zagadnień cenzurowania myśli ludzkiej w okresie komunizmu w Polsce oraz ograniczeń wolności słowa w państwach komunistycznych.

Kształtujące się od końca XVIII w. na świecie prawne uregulowania gwarantujące wolność słowa, po II wojnie światowej zaczęły nabierać wymiaru powszechnego, poprzez inkorporowanie regulacji wolnościowych do aktów prawa międzynarodowego, tj. Powszechna deklaracja praw człowieka. Ustawodawstwo państw komunistycznych, w tym ustawodawstwo po II wojnie światowej w Polsce, nie dostrzegało dokonujących się przekształceń w zakresie prawnych gwarancji wolności wypowiedzi. Marksiści nie uznawali praw i wolności jako kategorii naturalnych, przedpolitycznych, w przeciwieństwie do wywodzącej się z nurtu liberalnego wspomnianej wcześniej powszechnej Deklaracji czy późniejszego Międzynarodowego paktu praw obywatelskich i politycznych. W ujęciu marksistowskim wolność słowa i druku, w tym prasy, miała charakter klasowy, co oznaczało, że prasa miała służyć upowszechnianiu informacji niezbędnych klasie panującej do sprawowania władzy. W wyniku takiego rozumienia wolności prasy, w państwach komunistycznych, w tym także w Polsce, istniał system cezury prewencyjnej. Kilkanaście lat później Trybunał Konstytucyjny zdefiniował cenzurę prewencyjną jako przyznanie organom państwowym kompetencji do kontrolowania treści wypowiedzi przed ich publicznym rozpowszechnieniem, a także do uzależnienia przekazania wypowiedzi do publicznego odbioru od uprzedniej zgody $\mathrm{sądu}^{3}$. Z punktu widzenia historii prasy w Polsce należy go potraktować jako znaczący regres w ustawodawstwie polskim w porównaniu ze stanem sprzed II wojny światowej. Ograniczona w swoim działaniu prasa nie mogła spełniać podstawowych funkcji, jakie wyznacza jej nowoczesne społeczeństwo, w tym głównie funkcji kontrolnej społecznej oraz informowania społeczeństwa. Odbiciem „użyteczności” w myśleniu o wolnościach obywatelskich były zapisy Konstytucji PRL. W swoim tekście podstawowym z 1952 r. ${ }^{4}$ ustawodawca

1999; G. Majchrzak, Wojenna cenzura, „Biuletyn IPN”, 2004/2, s. 50-53; Ocenzurowano, oprac. G. Majchrzak, „Karta” 1999, nr 29; J. Kozłowski, Weryfikacja dziennikarzy prasowych w okresie stanu wojennego - podstawy faktyczne i prawne, przebieg, ocena prawnokarna pod katem przestępstw stanowiących zbrodnie komunistyczne w praktyce śledztw Oddziałowej Komisji w Łodzi z uwzględnieniem orzecznictwa sądów, (w:) Zbrodnie przeszłości, opracowania i materiały prokuratorów IPN, Tom 4, Ściganie, Warszawa 2012, s. 67-68.

${ }^{3}$ Treść orzeczenia Trybunału Konstytucyjnego, za E. Nowińska, Wolność wypowiedzi prasowej, Warszawa 2007, s. 98-100.

${ }^{4}$ Konstytucja Polskiej Rzeczypospolitej Ludowej z dnia 22 lipca 1952 r. Dz. U. 1952, Nr 33, poz. 232. 
deklarował, co prawda, wolność słowa i druku, ale jednocześnie zakładał, iż materialne gwarancje realizacji tych praw sprowadzają się do oddania w ręce ludu pracującego i jego organów, m.in. drukarni, zasobów papieru i środków łączności (art. 71).

Europejskie komunistyczne aparaty kontroli prasy konstruowane były na zasadzie podobieństwa do powołanego do życia przez Lenina w 1922 r. na mocy Dekretu o prasie tzw. Głównego Urzędu do Spraw Literatury i Wydawnictw (Glawlit) ${ }^{5}$.

Cenzura, rozumiana jako ocena, krytyka, sąd, wyrok $^{6} \mathrm{w}$ okresie PRL, w tym w okresie stanu wojennego, była zarówno cenzurą o charakterze politycznym, jak i prawnym. Oznacza to, że kontrolowano wypowiedzi pod kątem ich zgodności z polityką władz państwowych i promowanymi przez nie wartościami ${ }^{7}$. Podstawą dokonywania cenzury była oficjalna ideologia, czyli nawiązanie do pewnego wzorca odzwierciedlającego uznawane przez społeczeństwo i władzę wartości. Cechy te powodowały, że cenzura była ważnym elementem polityki państwa. Państwu zależało na tym, aby obywatele nie mówili głośno tego, co myślą i aby ich słowa były zgodne z określonym światopoglądem. Z drugiej strony, co pokazuje ustawodawstwo okresu stanu wojennego, władza starała się poznać, stosując mniej lub bardziej legalne metody, co obywatele myślą naprawdę 8 .

W odniesieniu do cenzury okresu PRL pojawia się w literaturze określenie - cenzura totalitarna, na określenie cenzury prewencyjnej - „odbierającej autorowi duszę". Cenzura ta była częścią omnipotentnego aparatu przemocy, starała się poddać kontroli cokolwiek zaistnieje w sferze publicznej, nie była nadto ograniczana prawem ${ }^{9}$. Wieloaspektowość cenzury w tym okresie trafnie opisuje Monika Wójciak:

„cenzura miała niezliczone wcielenia i formy, ale istota cenzorskiego zła tkwiła w zniewalaniu umysłów oraz charakterów. Zjawisko cenzury (...) wyrażało w istocie dążenie do całkowitej kontroli nie tylko zachowań, ale i świadomości ludzi poddawanych ideologicznemu praniu mózgów, (...) którego celem było stworzenie nowego typu człowieka"10.

${ }^{5}$ Dekret zabraniał publikowania prasy kontrrewolucyjnej, co było równoznaczne z przywróceniem cenzury. Szerzej M. Wójciak, Oblicza Gułagu, s. 172, (w:) Oblicza komunistycznego zniewolenia. Między nauka a literatura, pod red. K. Brzechczyna, Poznań 2009.

${ }^{6}$ Łacińskie pierwotne znaczenia - censeo - szacować (bo rzymski cenzor oceniał i szacował majątki).

${ }^{7}$ Encyklopedia Wiedzy Politycznej, pod red. M. Chmaja, J. Marszałek-Kawy, W. Sokoła, Toruń 2004, s. 40.

${ }^{8}$ Paradoks ten opisał Władimir Bukowski, radziecki dysydent. Cytuję za: A. Zybertowicz, Skryte oblicze systemu komunistycznego, Warszawa 1997, s. 155.

${ }^{9} \mathrm{Za}$ : Zabijanie stowa. O cenzurze w PRL z Aleksandrem Pawlickim, T. Strzemboszem, i W. Władyka rozmawiaja W. Buthak, i B. Polak, „Biuletyn IPN”, 2004, nr 2, s. 5.

${ }^{10}$ Ibidem, s. 172. 
Cenzura prawna wyrażała się natomiast w istnieniu prawa powszechnie obowiązującego, zakazującego publikowania określonych treści pod groźbą sankcji prawnych. W PRL, także w okresie stanu wojennego, funkcjonowała tzw. cenzura instytucjonalna. Można ją rozumieć jako istnienie wyspecjalizowanej instytucji, lub zinstytucjonalizowanych form działania, sprawujących kontrolę nad dopuszczaniem do rozpowszechnianiem wszelkich publikacji. Instytucje te były z początku agendami Ministerstwa Informacji i Propagandy, w lipcu 1946 r. zostały zastąpione Głównym Urzędem Kontroli Prasy, Publikacji i Widowisk (dalej GUKPPiW) ${ }^{11}$, później przemianowanym na Główny Urząd Kontroli Publikacji i Widowisk. Z biegiem lat urząd rozbudowywał się, zwiększała się liczba jego zdań, powoływano lokalne organy cenzury. Działalność tych instytucji przybierała częstokroć formy pozaprawne. Podczas dokonanej przez NIK w latach 60. kontroli urzędów wojewódzkich, wykazano, że brakowało podstawy prawnej działania aparatu cenzury w wielu województwach, w postaci statutów lub rozporządzeń wykonawczych do Dekretu. W drugiej połowie lat 60. uznano, że obowiązujący dekret jest „fatalny", ale wstrzymywano się z kompleksowym ujęciem cenzury w regulację ustawową z uwagi na możliwe negatywne skutki społeczne ${ }^{12}$. Pozaprawny charakter miały także tzw. instrukcje dla cezury sporządzane w formie zapisów. Ograniczenia te zbierane przez GUKPPiW, zaakceptowane przez czynniki partyjne, mogły pochodzić np. od instytucji państwowych i zakładów przemysłowych, wskazujących newralgiczne obszary wiedzy, na temat których nie powinno się pisać w prasie. Partia (PZPR) wyjaśniała natomiast ogólne zasady działań cenzorskich, opisując różnice między dozwoloną krytyką a krytykanctwem.

W tytule artykułu pojawia się sformułowanie ,prasa”. Obowiązujące przed 1984 r. ustawodawstwo nie definiowało pojęcia prasy, choć posługiwał się nim, obowiązujący do dnia wejścia w życie kodeksu karnego z 1969 r. ${ }^{13}$, Dekret Prezydenta RP z 21 listopada 1938 r. - Prawo prasowe ${ }^{14}$. Używał on pojęcia prasy w kontekście gwarancji jej wolności, stanowiąc, że ,granicą wolności prasy jest dobro powszechne". Dekret wyjaśniał natomiast pojęcia: druku (w ujęciu przedmiotowym), czasopisma oraz książki, które stanowiły przedmiot zainteresowania ustawodawcy.

${ }^{11}$ Dekret z dnia 5 lipca 1946 r., o utworzeniu Głównego Urzędu Kontroli Prasy, Publikacji i Widowisk, Dz. U. 1946, Nr 34, poz. 210. Celem dekretu było zapobieganie (prewencja) ukazywania się w prasie publikacji godzących w ustrój państwowy, naruszających prawo i dobre obyczaje, wprowadzanie w błąd opinii publicznej, poprzez publikowanie faktów niezgodnych z rzeczywistością.

12 Szerzej, Zabijanie słowa..., op. cit., s. 6.

13 Zdaniem Jacka Sobczaka Dekret z 1938 r. przestał obowiązywać z dniem wejścia w życie kodeksu karnego z 1969 r. Autor powołuje się na orzeczenie SN z 26 listopada 1970 r. Zob. J. Sobczak, Prawo prasowe, Warszawa 200, s. 58.

14 Dekret Prezydenta RP z 21 listopada 1938 r. Prawo prasowe, Dz. U. 1938 Nr 89, poz. 608. 
Uchwalony w 1946 r., a obowiązujący do 1984 r., Dekret o utworzeniu Głównego Urzędu Kontroli Publikacji, Prasy i Widowisk także używał pojęcia prasy, nie formułując jednak definicji legalnej ${ }^{15}$. Prasa obok publikacji i widowisk stanowiła przedmiot kontroli (cenzury prewencyjnej) dokonywanej przez władze państwowe. Postanowienia ustawy zostały w lipcu $1981 \mathrm{r}$. zmienione Ustawą o Kontroli Publikacji i Widowisk ${ }^{16}$, która podobnie jak poprzedniczki, nie definiowała legalnie pojęcia prasy. Ustawa dotychczas występujące pojęcia: dzienników, czasopism i książek, zastąpiła terminem publikacje.

Definicję legalną prasy wprowadziła do języka prawnego ustawa z dnia 26 stycznia 1984 r. Prawo prasowe ${ }^{17}$, obowiązująca, z pewnymi zmianami, do dzisiaj. Ustawa definiuje pojęcie w sposób szeroki, nazywając prasą:

publikacje periodyczne, które nie tworzą zamkniętej, jednorodnej całości, ukazujące się nie rzadziej niż raz do roku, opatrzone stałym tytułem albo nazwą, numerem bieżącym i datą, a w szczególności: dzienniki i czasopisma, serwisy agencyjne, stałe przekazy teleksowe, biuletyny, programy radiowe i telewizyjne oraz kroniki filmowe; prasą są także wszelkie istniejące i powstające w wyniku postępu technicznego środki masowego przekazywania, w tym także rozgłośnie oraz tele- i radiowęzły zakładowe, upowszechniające publikacje periodyczne za pomocą druku, wizji, fonii lub innej techniki rozpowszechniania; prasa obejmuje również zespoły ludzi i poszczególne osoby zajmujące się działalnością dzienni$\operatorname{karską}^{18}$.

Sposób interpretowania tego przepisu ulegał oczywistym zmianom na przestrzeni lat, dostosowując wolę historycznego ustawodawcy do każdoczesnych realiów. Jednak to literalne brzmienie nadane pojęciu należy przyjąć za obowiązujące na potrzeby niniejszego artykułu. Na taki sposób interpretowania wskazywać może także okres powstania ustawy. Pamiętajmy, że w momencie uchwalania ustawy Prawo prasowe funkcjonowała cenzura prewencyjna, a zapisy ustawowe są jej odzwierciedleniem. Wskazuje na to chociażby wyróżnienie prasy w znaczeniu przedmiotowym, do której zalicza także mało znaczące tele- i radiowęzły oraz przekazy teletekstowe, które ze swej istoty nie podlegają rozpowszechnianiu do nieokreślonego kręgu odbiorców. Zakwalifikowanie do kategorii prasy także publikacji o bardzo zróżnicowanej

${ }^{15}$ Dekret z 5 lipca 1946 r., o utworzeniu Głównego Urzędu Kontroli Prasy Publikacji i Widowisk, Dz. U. 1946, Nr 34, poz. 210.

${ }^{16}$ Ustawa z 31 lipca 1981 r., o Kontroli Publikacji i Widowisk, Dz. U. 1981, Nr 20, poz. 99.

${ }^{17}$ Zob. art. 7 ust. 2 pkt 1 Ustawy z dnia 26 stycznia Prawo prasowe Dz. U. 1984, Nr 5, poz. 24, z późn. zm.

${ }^{18}$ Szerzej na temat współczesnej wykładni art. 7 prawa prasowego (w:) Prawo prasowe. Komentarz, E. Ferenc-Szydełko, Lex 2013, lub starsze: J. Sobczak, Prawo prasowe. Komentarz, Lex 2008. 
wartości - od hobbystycznych po publikacje ukazujące się w prasie codziennej, wskazuje na bardzo szeroki zakres pojęcia. Dodatkowo do prasy zaliczono także zespoły ludzi zajmujące się działalnością dziennikarską (ujęcie podmiotowe).

II. Zaczątki zmiany systemowej w odniesieniu do prasy sięgają tzw. okresu przejściowego (1944-1947). Rozpoczęto wówczas stopniowe wprowadzanie rozwiązań systemowych, charakterystycznych dla państwa socjalistycznego, które koegzystowały z instytucjami i niektórymi zasadami ustrojowymi II RP ${ }^{19}$. Jednym z „nowych” rozwiązań było powołanie we wrześniu 1944 r. Resortu Informacji i Propagandy. Zakres działania tej instytucji określono w Dekrecie z 7 września 1944 r. ${ }^{20}$ Sprawy Resortu dotyczyć mogły: prasy codziennej i periodycznej, radiofonii, produkcji filmowej i kinematografii, propagandy w kraju i zagranica, wydawnictw propagandowych i informacyjnych ${ }^{21}$.

Kolejnym etapem było powołanie do życia w 1946 r. Głównego Urzędu Kontroli Prasy, Publikacji i Widowisk oraz podległych mu terenowych urzędów przy Radzie Ministrów ${ }^{22}$. GUKPPiW miał sprawować nadzór nad prasą, publikacjami i widowiskami oraz kontrolę nad rozpowszechnianiem utworów za pomocą druku, obrazu, żywego słowa.

W Dekrecie z 1946 r. sformułowano cele dokonywania kontroli. Były nimi zapobieżenie: godzenia w ustrój państwowy, ujawniania tajemnic państwowych, naruszania międzynarodowych stosunków państwa polskiego, naruszania prawa i dobrych obyczajów, wprowadzenia w błąd opinii publicznej poprzez podanie informacji niezgodnych z rzeczywistością.

W lipcu 1948 r. uprawnienia cenzury rozszerzono, na udzielenie zezwoleń (koncesji) na wydawanie czasopism i prawo kontroli nad zakładami poligraficznymi, a w 1952 r. cenzura objęła także zawiadomienia, plakaty, ogłoszenia i pieczątki.

Cechą charakterystyczną (istniejących do lipca 1981 r.) uregulowań był brak możliwości odwołania od decyzji cenzorskich. Akty prawne nie przewidywały także możliwości ujawnienia zakresu ingerencji cenzorskich.

${ }^{19}$ K. Krasowski, (w:) K. Krasowski, M. Krzymkowski, K. Sikorska-Dzięgielewska, J. Walachowicz, Historia ustroju państwa, Poznań 1994, s. 372-373.

${ }^{20}$ Dekret Polskiego Komitetu Wyzwolenia Narodowego z dnia 7 września 1944 r. o zakresie działania i organizacji Resortu Informacji i Propagandy, Dz. U. 1944 nr 4 poz. 20.

${ }^{21}$ Zdaniem Andrzeja Kozieła, Polska Partia Robotnicza mająca najsilniejszą pozycję wśród ugrupowań tworzących PKWN, zagwarantowała sobie w ten sposób bezpośredni oraz pośredni wpływ na wszelkie działające wówczas media, źródła informacji, tzw. propagandę masową oraz cenzurę. Powołanie resortu było decyzją polityczną podjętą z myślą o przyszłej nieuchronnej konfrontacji z opozycją. Szerzej A. Kozieł, Prasa w latach 1944-1989, (w:) Prasa, radio, telewizja w Polsce, Zarys dziejów, wyd. II, D. Grzelewska, R. Habielski, A. Kozieł, J. Osica, L. PiwońskaPykało, Warszawa 2001, s. 146.

${ }^{22}$ Dekret z dnia 5 lipca 1946 r. o utworzeniu Głównego Urzędu Kontroli Prasy, Publikacji i Widowisk, Dz.U. 1946, Nr 34, poz. 210. 
Symptomem pewnych korzystnych dla obywateli zmian prawa w zakresie cenzury była ustawa o kontroli publikacji i widowisk z lipca $1981 \mathrm{r}$. Uchwalenie jej nastąpiło w wyniku tzw. Porozumień sierpniowych, choć w kwestiach kluczowych znacznie odbiegała od wypracowanego przez strony Porozumienia ${ }^{23}$. Ustawodawca sformułował obszerny katalog informacji, które nie podlegały kontroli wstępnej Głównego Urzędu, cedując obowiązek dokonywania cenzury na organy, którym dany typ publikacji podlegał z racji kompetencji przedmiotowych, np. Ministerstwo Oświaty i Wychowania w zakresie akceptacji podręczników, Główny Urząd Geodezji i Kartografii - w zakresie akceptacji map. Zapis ten był przejawem rozluźnienia funkcjonowania cenzury w PRL. Podobną rolę odegrać mogły zapisy o konieczności zaznaczenia ingerencji cenzorach czterema kreskami umieszczonymi $\mathrm{w}$ kwadratowym nawiasie wraz z podaniem podstawy prawnej ingerencji. Ustawa spotkała się z dość zróżnicowanym przyjęciem przez środowiska naukowe. $Z$ jednej strony chwalono zrealizowanie Porozumień Gdańskich z sierpnia 1980 r., z drugiej dostrzegano niedookreśloność przepisów ustawy, mogącą prowadzić do dowolności interpretacyjnej, kwestionowano także konieczność istnienia cenzury instytucjonalnej ${ }^{24}$. Ustawa hołdowała koncepcji wolności słowa, jako prawa zależnego od nadania władzy, a nie prawa podmiotowego przynależnego obywatelom - każdemu bez względu na wolę władzy $^{25}$. Ustawa w pewnej części obowiązywała także w okresie stanu wojennego, najważniejsze jednak zmiany jakie wprowadzała zostały $\mathrm{w}$ tym okresie zawieszone.

III. W dniu 12 grudnia 1981 r. Rada Państwa uchwaliła Dekret o stanie wojennym ${ }^{26}$ i uchwałę (wykonawczą) w sprawie wprowadzenia stanu wojennego ze względu na bezpieczeństwo państwa ${ }^{27}$. Stan wojenny trwał do 22 lipca 1983 r., zniesiony uchwałą tego samego organu ${ }^{28}$. Wprowadzenie stanu wojennego władza uzasadniała, podając trojakiego rodzaju przyczyny:

${ }^{23}$ Szerzej na temat różnic między Porozumieniami a treścią ustawy zob. Z. Radziszewska, $Z$ historii walki o wolność słowa w Polsce, cenzura w PRL w latach 1981-1987, Kraków 1990, s. $5-9$.

${ }^{24}$ Szerzej J. Sobczak, Dzieje prawa prasowego na ziemiach polskich, Poznań 2009, s. 98.

${ }^{25}$ Szerzej Z. Radziszewska, op. cit., s. 5-9.

${ }^{26}$ Szerzej na temat wydawania dekretów w okresie PRL, zob. np. T. Mołdawa, Sejm Polskiej Rzeczypospolitej Ludowej, Warszawa 1987, s. 100. Sejm w okresie PRL nie miał wyłączności w sferze ustawodawczej. Rada Państwa miała prawo stanowić w okresach między sesjami Sejmu akty z mocą ustawy. Mołdawa twierdzi, że okres do 1956 roku charakteryzował się supremacją prawodawczą Rady Państwa, po 1956 r. zaobserwować można natomiast sytuację odwrotną, kiedy sejm stał się prawie wyłącznym prawodawcą.

${ }^{27}$ Uchwała z dnia 12 grudnia 1981r. w sprawie wprowadzenie stanu wojennego ze względu na bezpieczeństwo państwa, Dz. U. 1981, Nr 29, poz. 155.

${ }_{28}$ Uchwała Rady Państwa z dnia 20 lipca 1983 r., w sprawie zniesienia stanu wojennego, Dz. U. 1983, Nr 39, poz. 178. 
załamanie gospodarcze kraju, groźba anarchii, wojny domowej i przejęcia władzy przez Solidarność ${ }^{29}$.

Do Dekretu wprowadzającego stan wojenny wydano ponad 20 aktów wykonawczych ${ }^{30}$. Do najistotniejszych z punktu widzenia cenzury prasy należą:

1. Zarządzenie Ministra Spraw Wewnętrznych z dnia 12 grudnia $1981 \mathrm{r}$. w sprawie powołania organów cenzury przesyłek pocztowych, korespondencji telekomunikacyjnej oraz kontroli rozmów telefonicznych ${ }^{31}$.

2. Zarządzenie Prezesa Głównego Urzędu Kontroli Publikacji i Widowisk z dnia 12 grudnia $1981 \mathrm{r}$. w sprawie zasad i trybu udzielania zezwoleń na rozpowszechnianie publikacji i widowisk oraz postępowania przy użytkowaniu zakładów, urządzeń i aparatów poligraficznych w czasie obowiązywania stanu wojennego ${ }^{32}$.

3. Zarządzenie nr 2 Prezesa Rady Ministrów z dnia 12 stycznia 1982 r. w sprawie wykonywania przez korespondentów zagranicznych i dziennikarzy polskich czynności dziennikarskich na terytorium Polskiej Rzeczypospolitej Ludowej w czasie obowiązywania stanu wojennego ${ }^{33}$.

4. Rozporządzenie Rady Ministrów z dnia 12 grudnia 1981 r. w sprawie wykonania przepisów Dekretu o stanie wojennym w zakresie łączności ${ }^{34}$.

Wprowadzenie stanu wojennego Uchwałą z 12 grudnia 1981 r. spowodowało zaktualizowanie się przepisów Dekretu o stanie wojennym. Dekret w art. 4

${ }^{29}$ W okresie późniejszym, tj. od 1988 r. gen. Wojciech Jaruzelski, przewodniczący Wojskowej Rady Ocalenia Narodowego (dalej WRON), wskazywał na dwie dodatkowe przyczyny wprowadzenia stanu wojennego w 1981 r.: zagrożenie interwencją wojsk Układu Warszawskiego oraz naciski władz ZSRR. Twierdzenia te poddaje się krytyce, zob. np. W. Roszkowski, Najnowsza historia Polski 1980-1089, Warszawa 2011, s. 82. Zdaniem autora, stan wojenny wprowadzono, chcąc bronić istniejący system polityczny, poprzez rozbicie i zlikwidowanie „Solidarności” jako wielkiej siły społecznej niezależnej od władzy komunistycznej.

30 Poza wymienionymi aktami prawnymi, w okresie stanu wojennego powstawało (także w odniesieniu do cenzury) tzw. prawo powielaczowe. Pod pojęciem prawa powielaczowego przyjmuje się istnienie aktów normatywnych wydanych przez ministrów, a niekiedy przez inne podmioty (np. dyrektorów departamentów) w postaci instrukcji, wytycznych, regulaminów, okólników itp., nieogłaszanych w dziennikach publikacyjnych, lecz rozsyłanych w formie powielonego maszynopisu do adresatów - na ogół jednostek podporządkowanych w resortach. Szerzej na temat teoretyczno-prawnych zagadnień prawa powielaczowego zob. J. Jabłońska-Bonca, Prawo powielaczowe. Studium z teorii państwa i prawa, Gdańsk 1989. Definicja pojęcia z s. 3.

W okresie centralnego zarządzania w PRL, ,powielaczowy” sposób tworzenia prawa wykazywał się znaczną żywotnością. W okresie stanu wojennego do tzw. prawa powielaczowego zaliczyć można np. „Notatkę na temat głównych kierunków działania WPRiTV KC PZPR” (Wydział Propagandy Radia i Telewizji Komitetu Centralnego Polskiej Zjednoczonej Partii Robotniczej). Notatkę tę zawiera opracowanie: Stan wojenny w dokumentach wtadz PRL 1980-1983, pod red. B. Kopka i G. Majchrzaka, Warszawa 2001

${ }^{31}$ MP 1981, Nr 30, poz. 275.

${ }^{32}$ MP 1981, Nr 30, poz. 278.

${ }^{33}$ MP 1982, Nr 2, poz. 4.

${ }^{34}$ Dz. U. 1981, Nr 29, poz. 160. 
ust. 1 pkt 1 przewidywał, że wprowadzenie stanu wojennego powoduje czasowe zawieszenie lub ograniczenie określonych w Konstytucji PRL i innych ustawach oraz umowach międzynarodowych, których stroną jest Polska, podstawowych praw obywateli. Ograniczeniu lub zawieszeniu podlegały zarówno prawa o charakterze osobistym (np. nietykalność osobista), jak i politycznym, służące ochronie życia prywatnego jednostki przed nadmierną ingerencją ze strony państwa. Część praw uległa przekształceniu w obowiązek (prawo do pracy w stosunku do określonej kategorii osób) ${ }^{35}$. Z punktu widzenia prasy Dekret wprost ograniczał wolność słowa, druku oraz tajemnicę korespondencji, wyrażone m.in. w art. 1 ust. 1 ustawy o kontroli publikacji i widowisk z 31 lipca $1981 \mathrm{r}$.

IV. Z punktu widzenia cenzury prasy istotne zapisy znajdują się w art. 17 Dekretu, który stanowił, że kontroli prewencyjnej poddane zostanie rozpowszechnianie publikacji i widowisk za pomocą druku, obrazu i żywego słowa. Kontrolę sprawować miały organy kontroli publikacji i widowisk. Dekret przewidywał obligatoryjny zakaz udzielania zezwolenia w sytuacji, kiedy rozpowszechnienie publikacji lub widowiska zagrażałoby obronności państwa (art. 17. ust. 4).

Dekret w art. 17 wprowadzał zmiany w przedmiotowym zakresie cenzury w stosunku do stanu zapisów ustawy z 31 lipca 1981 r. o kontroli publikacji i widowisk, poszerzając go. Ustawa ta zawierała obszerny katalog wyłączony spod działań cenzorskich w art. 4.1., po wejściu w życie stanu wojennego katalog ten został umniejszony o następujące publikacje:

- publikacje naukowe i dydaktyczne szkół wyższych, placówek PAN, samodzielnych placówek naukowo-dydaktycznych, instytutów naukowobadawczych i placówek typu naukowo-badawczego utworzonych zgodnie z obowiązującymi przepisami, zakładów kształcenia duchownych i zarejestrowanych stowarzyszeń naukowych, a także druki tych instytucji służące zbieraniu danych do celów badawczych;

- prace przejściowe i magisterskie oraz prace dyplomowe, rozprawy doktorskie i habilitacyjne, wykonywane w ilościach niezbędnych do uzyskania dyplomu lub przeprowadzenia przewodu doktorskiego lub habilitacyjnego w instytucjach wyżej wymienionych;

- biuletyny zawierające informacje, w tym i opinie w sprawach dotyczących statutowej działalności oraz druki, formularze i zawiadomienia organizacji politycznych, związków zawodowych i innych organizacji społecznych

\footnotetext{
${ }^{35}$ Słusznie zauważa Bogdan Dobkowski w: Konstytucyjne aspekty stanu wojennego, s. 71, (w:) Stan wojenny $w$ Polsce. Refleksje prawno-polityczne, praca zbiorowa pod red. F. Prusaka, Warszawa 1982, że oprócz wskazanych w Dekrecie praw i wolności obywatelskich, które ten ograniczył lub zawiesił wprost, pośrednio wpłynął on na utrudnienia w wykonywaniu innych praw i wolności obywatelskich, np. prawa do korzystania z dóbr kultury.
} 
przeznaczone dla członków tych organizacji do wewnętrznego kolportażu i opatrzone taką klauzulą;

- wznowienia publikacji wydanych w Polsce Ludowej, które już uprzednio uzyskały pozwolenie na druk;

- publikacje utworów piśmiennictwa polskiego powstałych przed 1918 r.;

- wystawy plastyczne i fotograficzne o charakterze artystycznym;

- imprezy artystyczne lub rozrywkowe o charakterze wewnętrznym;

- druki artystyczne o charakterze oryginału; druki na prawach rękopisu w liczbie do 100 egzemplarzy ${ }^{36}$.

W katalogu treści nieocenzurowanych znalazły się m.in. treści dotychczas nie poddawane cenzurze $\mathrm{z}$ art. 4 ust. 1 ustawy o kontroli publikacji i widowisk, do których zaliczono:

- przemówienia posłów i radnych wygłoszone na jawnych posiedzeniach Sejmu i rad narodowych ora ich organów, jak również interpelacje i zapytania posłów i radnych;

- orzeczenia sądów i kolegiów ds. wykroczeń oraz organów orzekających w sprawach pracowniczych wraz z uzasadnieniem, chyba że jawność uzasadnienia została wyłączona;

- akty normatywne i inne akty prawne o charakterze ogólnym, w tym narodowe plany zagospodarowania przestrzennego, a także sprawozdania i opinie urzędowe;

- druki i formularze urzędowe organów państwowych i innych państwowych jednostek organizacyjnych, a także druki i formularze spółdzielczych i gospodarczych jednostek organizacyjnych, przeznaczone do użytku służbowego tych jednostek;

- publikacje statystyczne podlegające kontroli Głównego Urzędu Statystycznego;

- mapy samoistne i mapy stanowiące załączniki podlegające kontroli Głównego Urzędu Geodezji i Kartografii;

- podręczniki szkolne i pomoce dydaktyczne podlegające zatwierdzeniu przez Ministerstwo Oświaty i Wychowania;

- zaaprobowane przez Kościół katolicki i inne Kościoły oraz związki wyznaniowe pisma, obrazy, nagrania o charakterze przekazu wiary, dokumenty, teksty liturgiczne, teologiczne, zakonne, modlitewne, katechetyczne i duszpasterskie teksty prawa kościelnego, zawiadomienia, informatory, transmisje obrzędów religijnych w audycjach radiowych i telewizyjnych, imprezy kulturalno-religijne organizowane na terenie kościelnym, listy i pisma okólne przeznaczone do użytku wewnętrznego instytucji kościelnych oraz przeznaczone na użytek służbowy tych instytucji druki, formularze i inne dokumenty;

${ }^{36}$ Art. 17. 1 Dekretu poprzez odesłanie do art. 4 ustawy z lipca 1981 r. o kontroli publikacji i widowisk. 
- publikacje do użytku wewnętrznego Sił Zbrojnych i wewnętrzne imprezy wojskowe, podlegające kontroli wojskowych organów ochrony tajemnicy;

- nuty, płyty i nagrania zawierające wyłącznie muzykę;

- audycje radiofonii przewodowej;

- publikacje bibliograficzne oraz dane bibliograficzne;

- druki handlowe, firmowe oraz przeznaczone do użytku osobistego.

Ponadto Dekret (art. 17 ust. 2) zakazywał użytkowania osobom fizycznym, związkom zawodowym i organizacjom społecznym zakładów poligraficznych, urządzeń i aparatów wytwarzających druki i ilustracje wszelkim sposobem oraz zakładów wytwarzających pieczątki i stemple będących w ich posiadaniu. Innym podmiotom należących do państwowych i spółdzielczych jednostek organizacyjnych umożliwiono korzystanie $\mathrm{z}$ tych urządzeń, ale za pisemną zgodą i pod kontrolą zwierzchnika, np. ministra, prezesa spółdzielni lub wojewody.

Na podstawie delegacji zawartej w art. 17 Dekretu, Prezes Głównego Urzędu Kontroli Publikacji i Widowisk wydał Zarządzenie w sprawie zasad i trybu udzielania zezwoleń na rozpowszechnianie publikacji $i$ widowisk oraz postępowania przy użytkowaniu zakładów, urzadzeń $i$ aparatów poligraficz$n y c h w$ czasie obowiązywania stanu wojennego, w sposób istotny modyfikujące dotychczasowe postanowienia ustawy o kontroli publikacji i widowisk.

Zarządzenie precyzowało 9 kategorii działań, na które należało uzyskać zezwolenie organu kontroli publikacji widowisk (§ 1 ust. 2 i $\S 2$ ). Były to:

- rozpowszechnianie gazet, czasopism, książek i innych tekstów drukowanych;

- publiczne wystawienie utworu literackiego i mimicznego oraz wykonanie imprezy artystycznej i rozrywkowej; emisje widowisk telewizyjnych i audycji radiowych;

- rozpowszechnianie informacji emitowanych za pomocą radiofonii bezprzewodowej oraz telewizji;

- rozpowszechnianie nagrań magnetycznych;

- rozpowszechnianie filmów, przeźroczy, zdjęć i innych wyświetleń oraz wystawianie obrazów, zdjęć, plakatów i innych wytworów twórczości plastycznej;

- wydawanie gazet i czasopism; użytkowanie zakładów urządzeń i aparatów poligraficznych.

Zezwolenia na rozpowszechnianie publikacji i użytkowanie urządzeń poligraficznych wydawały: Główny Urząd Kontroli Publikacji, miejscowe urzędy kontroli publikacji i widowisk, ministrowie, kierownicy urzędów centralnych i instytucji, prezesi zarządów centralnych związków spółdzielni oraz wojewodowie. Tym samym utrzymano strukturę organizacyjną aparatu cenzury sprzed ogłoszenia stanu wojennego. Strukturę tę regulowała ustawa o kontroli publikacji i widowisk. 
Cenzor, dokonując kontroli publikacji prewencyjnej, kierował się następującymi kryteriami:

- ochrony niepodległości i integralności terytorialnej PRL;

- ochrony konstytucyjnego ustroju PRL;

- ochrony konstytucyjnych zasady polityki zagranicznej PRL;

- ochrony konstytucyjnych sojuszy PRL, ochrony stanu pokoju;

- ochrony tajemnic państwowej, służbowej i obronności;

- ochrony treści wiadomości z postępowania przygotowawczego i niejawnych wiadomości z rozprawy głównej;

- ochrony uczuć religijnych i postawy ateistycznej;

- ochrony równości pomiędzy obywatelami różnej narodowości i różnych ras;

- zagrożenia interesów bezpieczeństwa oraz obronności państwa (§ 4).

Naruszenie jednego z tych dóbr, np. konstytucyjnych zasad polityki zagranicznej PRL, powodowało wydanie odmowy udzielenia zezwolenia.

Zarządzenie przewidywało dwustopniową formę dokonywania cenzury. Pierwszy etap kontroli miał miejsce jeszcze przed powstaniem ich ostatecznej wersji i przygotowaniem do rozpowszechniania, np. drukiem. Drugi, wtedy gdy czasopismo już zostało wydrukowane, przedstawienie przygotowane etc. Wówczas organ kontroli mógł odmówić zgody na rozpowszechnienie, jeśli nie dostosowano się do wcześniejszych uwag cenzora. Decyzja ta nie podlegała zaskarżeniu i była ostateczna ${ }^{37}$.

Istotny z punktu widzenia tematu jest także zapis $\S 7$ cytowanego zarządzenia, na mocy którego z dniem wejścia z życie zarządzenia, utraciły moc dotychczasowe zezwolenia na wydawania gazet i czasopism.

V. Art. 18 Dekretu przyznawał Radzie Ministrów możliwość wprowadzenia, w drodze rozporządzenia, cenzury przesyłek pocztowych i korespondencji telekomunikacyjnej oraz kontroli rozmów telefonicznych. W tym celu miały zostać powołane (kompetencja łączna Ministra Spraw Wewnętrznych oraz Ministra Łączności) - organy cenzury łączności. Odrębne ograny, zwane w Dekrecie organami cenzury wojskowej, powoływać miał Minister Obrony Narodowej. Organy te zostały uprawnione do zatrzymania w całości lub w części przesyłek pocztowych i korespondencji telekomunikacyjnej oraz do przerywania rozmów telefonicznych, jeżeli ich treść może zagrażać bezpieczeństwu lub obronności państwa. Zatrzymane w drodze kontroli przesyłki pocztowe i korespondencja telekomunikacyjna podlegała przepadkowi na

${ }^{37}$ Zapis ten jest odbiciem tzw. ,zasady operatywności” organów administracji w okresie stanu wojennego, która polegała na tym, że ograniczone zostało prawo obywateli do dowoływania się od decyzji administracyjnych do wyższych instancji, przyjmując zasadę o ostateczności decyzji administracyjnych, z wyjątkiem sytuacji, gdy stronom przysługiwało odwołanie do organu II instancji na mocy Dekretu lub wydanego do niego aktu. Szerzej B. Dobkowski, op. cit., s. 74. 
rzecz Skarbu Państwa, bez odszkodowania. Spod działań cenzorskich wyłączono m.in. korespondencję między centralnymi i terenowymi organami partii, naczelnymi i terenowymi organami władzy i administracji państwowej oraz korespondencję tych organizacji z instytucjami i organizacjami, których działalności nie zawieszono po wprowadzeniu stanu wojennego.

Wydane na mocy Dekretu Rozporzadzenie w sprawie wykonania przepisów Dekretu o stanie wojennym w zakresie taczności, oprócz wprowadzenia cenzury krajowych i zagranicznych przesyłek pocztowych, korespondencji telekomunikacyjnej rozmów telefonicznych $(\S 1)$, zawieszało przyjmowanie paczek oraz przesyłek pocztowych z zawartością książek, prasy drukowanej i druków przeznaczonych do wysłania do obywateli za granicą. W ramach działań kontrolnych cenzor mógł m.in. zacierać informacje, których treść mogła zagrażać interesom bezpieczeństwa lub obronności Polski, lub występować z wnioskiem do resortu łączności o wyłączenie abonamentu.

Podobne postanowienia zawierało także wydane przez Ministra Spraw Wewnętrznych Zarządzenie $w$ sprawie powolania organów cenzury przesytek pocztowych, korespondencji telekomunikacyjnej oraz kontroli rozmów telefonicznych. Przewidywało ono powołanie dwustopniowych organów cenzury: Głównego Urzędu Cenzury MSW (GUC) oraz wojewódzkich urzędów cenzury, w liczbie 49, jako jednostek Milicji Obywatelskiej (WUC). Prowadziły one cenzurę $\mathrm{i}$ kontrolę w sposób selektywny i uzależniony od potrzeb. Wprowadzenie cenzury poprzedzono akcją w kwietniu 1981 r. o kryptonimie „Krokus-81”, prowadząc m.in. praktyczne ćwiczenia w zakresie techniki cenzorskiej. Na potrzeby cenzury przygotowano 4 rodzaje pieczątek z napisami: „ocenzurowano”, „,nie cenzurowano”, „wolne od cenzury”, „nie podlega cenzurze”. Ocenzurowane przesyłki były stemplowane pieczęcią „ocenzurowano" oraz pieczęcią urzędu cenzury z numerem identyfikacyjnym cenzora. $\mathrm{Na}$ podstawie porozumienia między MSW a Ministerstwem Łączności działalność poczty podporządkowano MSW. Korespondencja wpływała do wytypowanych węzłów pocztowych, zlokalizowanych w miejscowościach będących siedzibami WUC. Cenzurę paczek w obrocie krajowym powierzono natomiast wytypowanym pracownikom urzędów pocztowo-telekomunikacyjnych, pod nadzorem funkcjonariuszy MSW. Z danych dostępnych w literaturze wynika, że do końca 1982 r. ocenzurowano 82,8 mln przesyłek listowych, z tej liczby przekazano do wykorzystania operacyjnego 129 tys. przesyłek, a 9 tys. do wykorzystania procesowego. Skonfiskowano 930 tys. listów, teleksów i telegramów ${ }^{38}$.

Wprowadzenie cenzury rozmów telefonicznych, poprzez komunikat „rozmowa kontrolowana", miało natomiast głównie wymiar psychologiczno-

${ }^{38}$ Zdaniem Grzegorza Majchrzaka, cenzura korespondencji funkcjonowała z różnym nasileniem przez cały okres PRL, jedynie w okresie stanu wojennego była to działalność oficjalna. Majchrzak nazywa tę formę cenzury - perlustracją. G. Majchrzak, Wojenna cenzura, op. cit., s. 50-53. 
-zastraszający. Ówczesne państwo polskie nie dysponowało bowiem możliwościami technicznymi pozwalającymi na masową cenzurę rozmów telefonicznych ${ }^{39}$.

VI. Pośrednio także, bo w zakresie dostępu do prasy (do informacji), kwestie cenzury regulował art. 19 Dekretu. Stanowił on, że posiadacze radiowych urządzeń nadawczych i nadawczo-odbiorczych, jeśli wymagać tego będą interesy bezpieczeństwa lub obronności państwa, mogą zostać zobowiązani do złożenia do tych urządzeń do depozytu.

W momencie ogłoszenia stanu wojennego, postanowienia Dekretu zaktualizowały się i nastąpiło wstrzymanie stałej radiokomunikacji międzynarodowej oraz wszystkich łączy i traktów przewodowych i radiolinijnych relacji międzynarodowych, a także wstrzymanie pracy radiowęzłów publicznych (\$13 rozporządzenia). W opisywanym okresie początkowo funkcjonował tylko jeden program Polskiego Radia i jeden program Telewizji Polskiej, zawieszono działalność regionalnych ośrodków radia i telewizji Działalność programu II PR wznowiono 17 stycznia 1982 r., programu IV - 15 lutego 1982 r., a programu III - 5 kwietnia 1982 r. ${ }^{40}$

Zakazano funkcjonowania i zakładania amatorskich i doświadczalnych urządzeń radiowych nadawczych i odbiorczych. Uchylono ważność dotychczasowych zezwoleń na używanie radiostacji osobistych lub klubowych $(\S 17$ rozporządzenia). Posiadacze takich urządzeń zostali zobligowani do złożenia urządzeń w depozyt. Bez ograniczeń funkcjonowały urządzenia łączności MSW i MSZ. Jednostki organizacyjne administracji państwowej mogły natomiast używać urządzeń łączności wyłącznie w celach służbowych.

VII. Z punktu widzenia cenzury prasy warto też zwrócić uwagę na art. 20 Dekretu, dający wojewodzie prawo wydawania zakazu fotografowania i filmowania oraz dokonywania obrazów telewizyjnych określonych obiektów i miejsc, w przypadku gdy uzna on, że wymagają tego względy bezpieczeństwa lub obronności państwa. Naruszenie normy było karane (art. 49 ust. 6), karą aresztu do 3 miesięcy albo karą grzywny do 5000 złotych. W razie skazania sąd mógł orzec przepadek narzędzi i innych przedmiotów, które były przeznaczane do popełnienia przestępstwa, chociażby nie stanowiły własności sprawcy.

\footnotetext{
${ }^{39}$ Ibidem, s. 53.

${ }^{40}$ Szerzej 1982 styczeń 4, Warszawa, Notatka na temat głównych kierunków działania WPR i TV KC PZPR związanych z wprowadzeniem stanu wojennego 13 grudnia 1981, Główne kierunki działania Wydzialu Prasy, Radia i Telewizji KC PZPR zwiazane z wprowadzeniem stanu wojennego 13 grudnia 1981 r., (w:) Stan wojenny w dokumentach władz PRL 1980-1983, wybór, wstęp i opracowanie B. Kopka, G. Majchrzak, Warszawa 2001, s. 112-113.
} 
VIII. Swoisty rodzaj cenzury wprowadziło Zarzadzenie $n r 2$ Prezesa Rady Ministrów w sprawie wykonywania przez korespondentów zagranicznych i dziennikarzy polskich czynności dziennikarskich na terytorium PRL w czasie obowiazywania stanu wojennego. Zarządzenie odmiennie regulowało status grupy zawodowej dziennikarzy w odniesieniu do dziennikarzy zagranicznych, polskich oraz wojskowych. Wspólnym uregulowaniem była konieczność starania się o uzyskanie legitymacji (wizy czasowej w przypadku dziennikarzy zagranicznych przebywających czasowo) oraz zezwolenia, związanych z wykonywaniem zawodu w czasie stanu wojennego. Dziennikarze polscy uzyskiwali zezwolenia czasowe na określony obszar, ich działalność publikatorska podlegała nadto reżimowi cytowanego wcześniej Zarzadzenia $w$ sprawie zasad i trybu udzielania zezwoleń na rozpowszechnianie publikacji $i$ widowisk (...). Zarządzenie wprowadzało także tzw. zezwolenie specjalne, wydawane przez Szefa Głównego Zarządu Politycznego Wojska Polskiego, zarówno dla dziennikarzy polskich, jak i korespondentów zagranicznych, gdy zbierali oni materiały dotyczące problematyki wojskowo-obronnej.

Równolegle z wprowadzaniem zmian prawa Centralny Sztab Propagandy i Informacji KC PZPR dokonywał weryfikacji dziennikarzy prasy, radia i telewizji oraz weryfikacji pracowników wydawnictw i służb pomocniczych radia i telewizji. Jako cel weryfikacji, jak podaje Jacek Kozłowski ${ }^{41}$, określono: „dokonanie oceny linii redakcyjnej poszczególnych zespołów, a także twórczości dziennikarskiej, aktywności i postawy poszczególnych dziennikarzy w okresie od sierpnia 1980 r. oraz określenie stosunku do decyzji z 13 grudnia 1981 r."

W wyniku prowadzonych przez wojewódzkie komisje weryfikacyjne rozmów w styczniu i lutym 1982 r., dokonano negatywnej weryfikacji 500 pracowników koncernu RSW Prasa-Książka-Ruch. Zwolniono 302 osoby, a 180 skierowano do pracy poza koncernem. Odwołano 60 redaktorów naczelnych, 78 ich zastępców oraz 57 redaktorów redakcji. W Komitecie ds. Radia i Telewizji decyzje kadrowe podjęto w stosunku do 227 dziennikarzy i 300 pracowników technicznych. W czasopismach wydawanych poza RSW Prasa-Książka-Ruch negatywnie zweryfikowano 100 dziennikarzy, odwołując 15 redaktorów naczelnych. Ten sam autor podaje, cytując źródła Wydziału Prasy Radia i Telewizji KC PZPR, że w całym kraju na skutek weryfikacji pracę utraciło ponad 800 dziennikarzy i około 300 pracowników technicznych, co w sumie stanowiło $10 \%$ środowiska ${ }^{42}$.

Równolegle z weryfikacją kadr dziennikarskich przyjęto zasadę, że każda organizacja młodzieżowa dysponować ma swoim organem prasowym, a w każdym województwie ma istnieć tygodnik partyjny. Wydawanie gazet

\footnotetext{
${ }^{41}$ Szerzej J. Kozłowski, Weryfikacja..., op. cit., s. 67.

${ }^{42}$ Ibidem, s. 68.
} 
partyjnych oraz ich kolportaż miała zapewnić spółdzielnia Prasa-KsiążkaRuch. Dzienniki terenowe miały być redagowane przez wytypowane zespoły dziennikarskie gazet z udziałem wytypowanych dziennikarzy z pozostałych dzienników. Odpowiedzialność za treść gazet miała spoczywać na wojewódzkich sztabach informacji i propagandy, z udziałem pełnomocników sztabu centralnego. Jednocześnie powołano do działania partyjną agencję o nazwie Krajowa Agencja Robotnicza, stanowiącą serwis publicystyczny dla prasy, radia $\mathrm{i} \mathrm{TV}$, zawłaszcza dla prasy terenowej.

IX. Inne przepisy o charakterze prawnokarnym dotyczące prasy znajdują się $\mathrm{w}$ art. 48 ust. 1-6.

Art. 48 ust. 1 zakazywał działań polegających na rozpowszechnianiu wiadomości mogących osłabić gotowość obronną PRL. Popełnienie przestępstwa zagrożone było sankcją pozbawienia wolności do 8 lat. Przez rozpowszechnianie rozumieć należy takie rozgłaszanie, które prowadzi do podania danej informacji do wiadomości szerokiego i nieograniczonego kręgu osób. Udzielenie informacji jednej lub kilku osobom nie wyczerpuje znamion tego przestępstwa. Zagrożenie następuje wtedy, gdy zakres rozgłaszanych informacji może osłabić gotowość obronną, nawet jeśli są one zgodne z prawdą. Do dokonania przestępstwa nie jest jednak konieczne, aby ten skutek faktycznie nastąpił.

Art. 48 ust. 2 ustawodawca zakazał rozpowszechniania wiadomości fałszywych, jeżeli może to wywołać niepokój publiczny lub rozruchy. Czyn ten zagrożony był sankcją karną od 6 miesięcy do 5 lat pozbawienia wolności. Była to sankcja wyższa niż ta przewidziana w art. 271 kk z 1969 r. Kodeks za czyn polegający na rozpowszechnianiu fałszywych informacji, jeżeli może to wyrządzić poważną szkodę interesom PRL, przewidywał sankcję do 3 lat pozbawienia wolności. Za wiadomości fałszywe uznać należy wiadomości niezgodne z rzeczywistością. Rozpowszechnianie wiadomości nieprawdziwych mogło być uznane za przestępstwo, wtedy gdy mogło wywołać niepokój publiczny w ten sposób, że rodziło nieposłuszeństwo wobec władzy skutkujące np. podpalaniem, niszczeniem etc.

Art. 48 ust. 3 penalizował sporządzanie, gromadzenie, przechowywanie, przewożenie lub przesyłanie pisma, druku, nagrania lub filmu w odniesieniu do wiadomości mogących osłabić gotowość obronną PRL lub fałszywych wiadomości mogących wywołać niepokój publiczny lub rozruchy. Czyn ten zagrożony był sankcją do 5 lat pozbawienia wolności.

Wyższą sankcję ustanowiono w stosunku do sprawców tego samego czynu, którzy używali druku lub innego środka masowej informacji (kara pozbawienia wolności od 1 roku do 10 lat) (art. 48 ust. 4).

W przypadku każdego z wymienionych powyżej czynów sąd mógł orzec przepadek narzędzi i innych przedmiotów, które służyły lub były przeznaczo- 
ne do popełnienia przestępstwa, chociażby nie stanowiły własności sprawcy (art. 48 ust. 6).

Ustawodawca nałożył nadto obowiązek denuncjacji, właściwym organom ścigania, na każdego, kto ma wiarygodne wiadomość o czynach określonych w ust 1-3 art. 48. Niewykonanie obowiązku zagrożone było sankcją pozbawienia wolności od 6 miesięcy do 5 lat (art. 48 ust. 5). Obowiązany mógł zwolnić się z tego obowiązku poprzez wykazanie, że zaniechał powiadomienia, mając dostateczną podstawę do przypuszczenia, że organ ścigania wie o fakcie przestępstwa lub z obawy przed odpowiedzialnością karną grożącą jemu samemu lub najbliższym.

Podsumowanie. Wprowadzenie stanu wojennego spowodowało zawieszenie liberalizujących cenzurę przepisów nowelizacji ustawy o kontroli publikacji i widowisk. Ustawa ustanawiała dwuszczeblową strukturę organów kontroli: okręgowe urzędy - działające jako organy pierwszej instancji oraz organ odwoławczy, Główny Urząd. W sposób szczegółowy określała, jakie informacje i w jakim czasie mają być dostarczone do okręgowych urzędów w celu wydania zgody na ich rozpowszechnienie. Określono terminy wydawania przez urzędy okręgowe decyzji dopuszczających rozpowszechnienie lub niedopuszczających w części lub w całości. W art. 14 ustanowiono obowiązek podania miejsca oraz podstawy prawnej ingerencji cenzury w druk. Wprowadzono możliwość odwołania od decyzji cenzorskich.

Podsumowując cenzorską działalność władz w okresie stanu wojennego w odniesieniu do prasy, wskazać należy na pewne podobieństwa oraz różnice w sposobie regulacji w stosunku do całego okresu PRL. Cechami wspólnymi są:

- polityczny charakter cenzury, rozumiany jako kontrola wypowiedzi pod kątem ich zgodności z polityką władz państwowych i promowanymi przez nie wartościami oraz traktowanie cenzury jako instrumentu sterowania procesami społecznymi przez władzę państwową;

- charakter instytucjonalny, gdyż w okresie PRL istniał Główny Urząd Kontroli Prasy, Publikacji i Widowisk, później przemianowany na Główny Urząd Kontroli Publikacji i Widowisk. Istniał też wyspecjalizowany aparat propagandy pośrednio kontrolujący treść informacji. Regulacja miała charakter pozaustawowy (dekrety);

- charakter prewencyjny cenzury.

Odrębności w regulacji prawnej okresu stanu wojennego wynikały z przewidzianych Dekretem o wprowadzeniu stanu wojennego oraz uchwała (go wykonującą) ograniczeń konstytucyjnych praw i wolności, w tym wolności słowa, i polegały na:

- kazuistycznym charakterze unormowań zawartych w aktach wykonawczych do Dekretu; 
- poszerzeniu zakresu przedmiotowego działania organów cenzury o ograniczenia związane z publicznymi imprezami (np. artystycznymi czy sportowymi), cenzurę przesyłek pocztowych i prywatnej korespondencji;

- wprowadzeniu dodatkowych kryteriów dokonywania cenzury: zagrożenie interesów bezpieczeństwa oraz obronności państwa;

- ustanowieniu odrębnych, surowszych regulacji prawnokarnych;

- poszerzeniu cenzury prawnej o wymiar prywatny funkcjonowania jednostki - korespondencja;

- rozszerzeniu kompetencji organów administracyjnych i kompetencji kierowników zakładów pracy w zakresie spraw objętych ograniczeniami stanu wojennego. Realizowano je m.in. poprzez zwiększenie operatywności organów administracji i zakładów pracy oraz zastąpienie kontroli administracji państwowej kontrolą wojskowych organów stanu wojennego.

Inny wymiar cenzury prasy dotyczy jej faktycznego funkcjonowania. Wielu dziennikarzy zostało wówczas pozbawionych możliwości wykonywania zawodu, zamknięto szereg redakcji, zawieszono czasowo działalność regionalnych ośrodków radia i telewizji. Działalność pozostałych, kontrolowana była m.in. za pomocą systemu wydawanych przez państwo legitymacji i zezwoleń.

Wydaje się, iż uprawniona jest teza, że stosunek państwa do wolności słowa jest papierkiem lakmusowym ideologii i celów rządzących.

\section{LEGAL GROUNDS OF PRESS CENSORSHIP DURING MARTIAL LAW IN POLAND (1981-1983)}

\section{Summary}

This paper focuses on the functioning of press censorship in martial law Poland between 13 December 1981 and 22 July 1983, analysed through the prism of legal limitations. Separate legal regulations to be binding at the time of martial law were laid down in the Decree on martial law and following it enforcement act setting out restrictions on constitutional rights and freedoms, including the freedom of speech. Thus censorship activity was strengthened and extended, public events (including sports competitions and artistic performances) limited, and private correspondence censored. The list of reasons for censoring also became longer to accommodate such reasons as public interest or state security, and the competences of administrative bodies and employers associations of state-owned enterprises increased. 


\section{LES BASES JURIDIQUES DE LA CENSURE DE LA PRESSE PENDANT L'ÉTAT DE SIÈGE EN POLOGNE (1981-1983)}

\section{Résumé}

L'objet du présent texte est le fonctionnement de la censure de la presse pendant l'état de siège (du 13 XII 1981 au 22 VII 1983) en Pologne, vue à travers le prisme des restrictions juridiques. Les particularités du règlement juridique de cette période résultent des restrictions constitutionnelles aux droits et libertés, prévues par le Décret proclamant l'état de siège et la loi (arrêté d'application) sur la limitation constitutionnelle des droits et libertés, y compris la liberté d'expression. Les restrictions consistent, entre autres, en l'élargissement de l'étendue des activités menées par les organes de la censure, la mise en place des restrictions liées aux manifestations publiques p.ex. artistiques ou évenements sportifs, la censure postale (inspection ou examen des colis expédiés et de la correspondance privée), la mise en place des critères supplémentaires de censure : le risque pour les intérêts de la sécurité et de la capacité de défence de l'État; la mise en place des régulations à part du droit pénal, plus rigoureuses; l'intégration dans la notion de la censure juridique de la dimension privée du fonctionnement de l'individu - échange de courriers; octroi des compétences plus larges à l'administration et aux responsables des établissements de travail en matière des affaires soumises aux restrictions liées à l'état de siège. 
